\title{
THE PSYCHOLOGICAL AND COGNITIVE BENEFITS OF MULTILINGUALISM
}

\author{
${ }^{1}$ Sayfullaeva Yulduz, ${ }^{2}$ Surmanov Sardor, ${ }^{3}$ Azimova Maftuna
}

${ }^{1}$ ESP lecturer, Tashkent State University of Law, Tashkent, Uzbekistan.E-mail: y.sayfullaeva@tsul.uz ${ }^{2}$ ESP Instructor, Tashkent State University of Law, Tashkent, Uzbekistan.E-mail: s.surmanov@tsul.uz ${ }^{3}$ EFL teacher, Tashkent State University of Uzbek Language and Literature, Tashkent, Uzbekistan.E-mail: azimova@navoiyuni.uz

\section{ABSTRACT}

This article looks into the ways how acquisition of several languages benefits people psychologically and cognitively. In the initial chapters the article provides data about the prior research that has been carried out about the effects of language learning on human mind following which it analyzes the survey results where over 30 participants shared information about the effects of languages on their individuality as well as their cognition. Furthermore, they answered questions about the impact of multilingualism on their personality.

Keywords:

multilingualism, cognition, communication, multitasking, monolingual, memory enhancement, cognitive skills.

Article Received: 18 October 2020, Revised: 3 November 2020, Accepted: 24 December 2020

\section{INTRODUCTION}

Learning foreign languages is generally a positive experience as it gives people a chance to discover a new culture, creates an opportunity to make new friends from different backgrounds, enhances people's multitasking abilities and most importantly keeps the brain active. Based on the research carried out at the York University in Toronto, Canada, it was discovered that bilingual children were faster at multi-tasking than monolingual kids. This study was conducted by by Raluca Barac and Ellen Bialystok who tested a total of 104 children. In this study bilingual and monolingual children were supposed to press the keys of the computer as on the screen various images were displayed, the images were either of animals or of demonstration of various colors. When they were to choose only one, both monolingual and bilingual kids performed at the same pace. However, when the kids were told to switch between animals and colors, bilingual kids were much faster at making the changes than monolinguals. This research shows that kids who can communicate in two languages have better mental process of executive functioning- which involves the ability to pay attention, plan, organize, and strategize. The task of pressing keys engages three mental processes: the ability to keep a rule or principle in mind (working memory), inhibition (the ability to refrain from carrying out one rule), and shifting (the ability to make the change and act on another rule). In addition, learning foreign languages has a positive impact on adults as it is claimed to slow down the symptoms of Alzheimer's disease, as doing exercises helps the body to keep active and strong, learning languages keeps adult mind fresh and active, improving cognitive skills.

How about the effect of language learning on healthy people? "Almost everyone has a desire to speak a foreign language, to be able to communicate" (Umida Khaydarova, Noila Mustafaeva, Bakhodir Abdurakhmonov, 2020). Truly, many try to learn a new language although they have little information about the positive effects of it.

Those who are undergoing normal cognitive aging do seem to take no notice of irrelevant information and deal with conflicts and clashes much better than monolingual people. Interestingly, as it was mentioned about children, adults who are mono (bi) lingual are better at 
switching from one task to another. In the next chapter there will be more information provided about the psychological impact of learning languages.

THE PSYCHOLOGICAL BENEFITS OF MULTILINGUALISM

Knowledge of multiple languages has three main advantages: it makes people more tolerant of ambiguity, enhances decision making and ameliorates communication skills.

Multilingual individuals are believed to develop ambiguity tolerance that is they cope with uncertainties rather easily and are open to practices and beliefs of others. It in its turn, contributes to "cross-cultural endeavors and settings" which means a person can build a career in various work environments, cope with tasks more easily as they are more open to new ideas (Herman et al. 2010; Tang, Yin, and Nelson 2010; Lee, Gettman, and Swanson 2013). In addition, multilingualism makes a person multicultural which implies they become more aware of other cultures and treat them with understanding and respect interpreting what the representatives of various cultures say in a proper way as a result of developed tolerance of ambiguity.

Language learning also impacts decision making skills, due to their language skills, polyglots feel calm and at ease when they encounter various problems or are supposed to make some decisions, be it serious or related to daily activities. It is important to mention that they are usually not afraid of taking risks either. As it has been suggested by the research, acquisition of a foreign language can increase individuals' eagerness to take risks as they are not emotionally attached to the language as to their native one (Sayuri Hayakawa et al, 2018).

The last but not least, language learning can positively reflect upon multi-linguals' social lives as their communication skills are believed to develop as they require new languages. Based on the evidence from the research with older children, bilingual and multilingual children can comprehend abstract notions better, use more complex linguistic features in their speech and surprisingly, kids are good at code switching to prevent communication misinterpretations and are good at changing their register of speech depending on who their interlocutors are (BenZeev, 1977; Bialystok \& Barac, 2012a; ByersHeinlein \& Werker, 2009; Cummings, 1987; Davidson \& Tell, 2005; Galambos \& Goldin-Meadow, 1990; Galambos \& Hakuta, 1989; Hakyta, 1987; Healey \& Skarabela, 2008; Ianco-Worrall, 1972). Taken these all into consideration, it can be concluded that multilingualism has a number of positive effects on individuals' lives including developed tolerance of ambiguity, better decision making competence and enhanced communication skills.

\section{MATERIALS AND METHOD}

In order to put the theory into practice, there was a research carried out among multilingual individuals. The research took place in the form of a questionnaire and there were 30 people involved in it. One third of them are teachers who have a good command of 4 languages and the rest are students learning a third language. The survey consisted of questions concerning individuals' cognitive skills and emotional states when they communicate in different languages. In addition, the questions covered topics like memory improvement and the enhancement of speaking skills as a result of communicating in different languages.

The aims of the survey were to identify:

1) The effects of learning languages on people's memory

2) The impact of learning languages on emotional states

3) The influence of languages on socialization

4) The connection between learning languages and multitasking $\backslash$ prioritizing

5) The effect of languages on individuals' character and behavior.

The results of the survey will be discussed in the next chapter. 


\section{DISCUSSION}

Based on the micro research, it can be concluded that all the polyglots have been influenced by the process of language learning, to be precise, $100 \%$ of all the participants affirmed that their cognitive skills including reasoning competence have been improved (chart 1).

\section{Has learning new langugages helped you to develop your cognitive skills ( e.g. to think better, to reason)?}

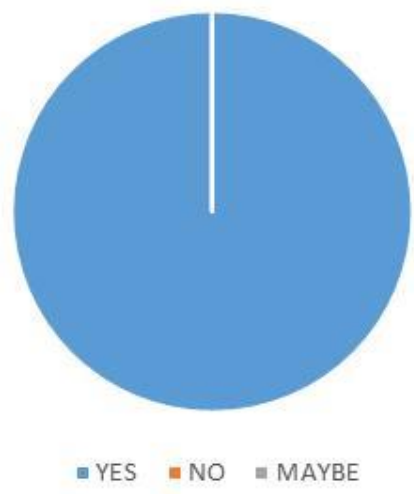

Regarding the improvement of memory as a result of learning languages, more than 70 percent of the partakers claimed that it has been improved; the other 15 stated that their memory has not been influenced and the rest of the participants stated they were not sure whether their memory competence have been affected anyhow.

\section{Has your memory improved after acquiring new language skills?}

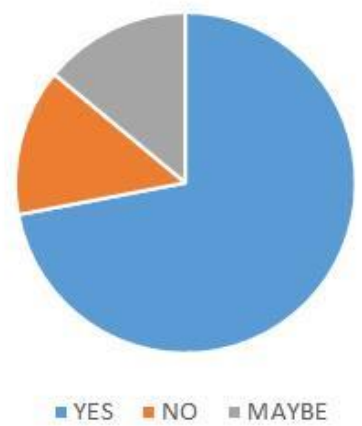

As for the change in individuals' emotional conditions, over half of the participators stated that they move from one emotional condition to another when they use different languages, 35\% of the people stated the use of languages has no impact on their emotional state. Finally the rest 7.1 percent claimed that their attitudes to things around them change but not their emotional state.

Concerning the multitasking related question, again the majority, more than 70 percent of the individuals stated their competence of doing multiple tasks simultaneously has improved.

\section{CONCLUSION}

The aim of the current article was to identify the cognitive and psychological benefits of being a multilingual and it has been discovered that polyglots do have privileges over monolinguals and such advantages include better verbal and social skills, stronger determination, mastery in multitasking and prioritizing, inhibition of symptoms of illnesses including the Alzheimer's and. However, as every coin has a flip side, multilingualism also has some negative aspects too. For instance, multilingual individuals 
may find it hard to switch from one language to another or they may experience challenges in blending with monolingual people. Still, being a multilingual gives myriads of opportunities and has immensely positive influence on people's cognition which is why advantages surely prevail the drawbacks of being a plurilingual.

\section{REFERENCES}

[1] Akobirova, S. T., Rasulmukhamedova, U. A., \& Surmanov, S. E. (2020). PECULARITIES OF IMPLICITNESS IN ARTISTIC TEXT. Theoretical \& Applied Science, (2), 158-161.

[2] Ametova, O. R., \& Mustafoeva, N. I. (2020). The benefits and drawbacks of online education for law students in higher educational institutions. ISJ Theoretical \& Applied Science, 12(92), 61-63.

[3] Azimova Maftuna (2020). Self-confidence in oral performance. Бюллетень науки и практики, 6 (4), 444-452.

[4] Dewaele, Jean-Marc and Li, Wei (2013) Is multilingualism linked to a higher tolerance of ambiguity? Bilingualism: Language and Cognition 16 (2), pp. 231-240.

[5] Dildora Abduazizovna Usarova (2021). PRAGMATIC ASPECTS OF INTERPRETATION. Academic research in educational sciences, 2 (1), 410-414. doi: 10.24411/2181-1385-2021-00051

[6] Hubscher-Davidson, Severine (2018). Do Translation Professionals Need to Tolerate Ambiguity to be Successful? A Study of the Links between Tolerance of Ambiguity, Emotional Intelligence and Job Satisfaction. In: Lacruz, Isabel and Jääskeläinen, Riitta eds.by S Hubscher-Davidson · 2018

[7] Ishnazarovna, M. N. (2020, December). IMPROVEMENT OF STUDENTS WRITTEN COMPETENCE WHEN WORKING WITH OFFICIAL DOCUMENTS BASED ON FOREIGN EXPERIENCE. In Archive of Conferences (Vol. 10, No. 1, pp. 65-67).
[8] Mirgiiazova, M. M. (2019). Scientific approaches to teaching foreign languages. Молодой ученый, (47), 37-39.

[9] Mustafakulovich, R. M., Shokirovich, T. O., \& Ishnazarovna, M. N. (2020). SIMULTANEOUS INTERPRETING AS A SPECIAL INTERPRETER ACTIVITY. PROS AND CONS OF SIMULTANEOUS INTERPRETING. Oriental Art and Culture, (V).

[10] Nigorakhon Rakhimovna Ruzibaeva (2021). COGNITIVE LINGUISTICS: BASIC CONCEPTS. Academic research in educational sciences, 2 (1), 438-446. doi: 10.24411/2181-1385-2021-00055

[11] Rozmatovna, A. O. (2020). The influence of integrative motivation and instrumental motivation on learning English as a Foreign Language. Journal of Critical Reviews, 7(12), 942-945.

[12] Ruzibaeva, N. (2019). PECULIARITIES OF THE ANTITHESIS IN THE LITERARY TEXT. European Journal of Research and Reflection in Educational Sciences Vol, $7(11)$.

[13] Sardor Egamovich Surmanov, \& Maftuna Ilkhom Kizi Azimova (2021). FORMATION OF READING SKILLS IN YOUNG LEARNERS. Academic research in educational sciences, 2 (1), 461-467. doi: 10.24411/2181-1385-2021-00058

[14] Sayfullaeva, Y. E. (2020) Implementation of role-play and simulation activities while teaching ESP students, 10.5958/22497137.2020.01866.2 , Academicia, an International Multidisciplinary Research Journal

[15] Shokirovich, T. O., \& Abdijalilovna, Z. D. (2020). Teaching EFL and ESP for Law. Activities and challenges during the covid19 pandemic in Uzbekistan. Solid State Technology, 63(6), 8318-8325.

[16] Surmanov, S. (2020). ANALYSIS OF DIFFICULTIES IN VOCABULARY 
ACQUISITION. The Journal of Legal Studies, 6(1), 144-153.

[17] Surmanov, S. (2020). ROLE GREADED READERS IN DEVELOPING VOCABULARY. Personal and Professional Development, 1(1), 40-43.

[18] Togaymurodova, R., Hamraev, N., Buriyeva, G., \& Surmanov, S. (2019). RENOVATION IN TASHKENT INSTITUTE OF RAILWAY ENGINEERING. European Journal of Research and Reflection in Educational Sciences Vol, 7(12).

[19] Umida Khaydarova, Noila Mustafaeva, Bakhodir Abdurakhmonov. (2020). ISSUES ON INCREASING MOTIVATION IN LANGUAGE LEARNING PROCESS. International Journal of Advanced Science and Technology, 29(05), 1479 - 1482. Retrieved from http://sersc.org/journals/index.php/IJAST/art icle/view/10052

[20] Urunov, B. I., Mirgiyazova, M. M., \& Saidova, M. S. (2020). THE PEDAGOGICAL CONDITIONS FOR EFFECTIVE TRAINING LANGUAGE TEACHERS PROFESSIONAL DEVELOPMENT NEW METHODS AND TECHNOLOGIES. Theoretical \& Applied Science, (4), 1017-1019.

[21] Yuldashevna, M. M. (2019). THE INTERPRETATION OF THE CONCEPT" KNOWLEDGE" IN ENGLISH LITERATURE. European Journal of Research and Reflection in Educational Sciences Vol, 7(10).

[22] Zoyirova, D. A. (2018). Forming Discursive Competence of Law Students. Eastern European Scientific Journal, (6).

[23] Миргиязова, М. М. (2017). Innovative technologies in teaching English. Молодой ученый, (25), 301-302.

[24] https://docs.google.com/forms/d/16v2iybwb 4-Gy-
m4P2GLRayn6VIkNsKo1NMNHtgC1aPI/e dit\#responses

[25] https://www.alsintl.com/blog/thinking-in-aforeign-language-improves-decisionmaking/

[26] https://www.nih.gov/news-events/newsreleases/bilinguals-switch-tasks-fastermonolinguals-nih-funded-studyshows\#: :text=Bilinguals\%20slower\%20to $\%$ 20build $\% 20$ vocabulary, the $\% 20$ National $\%$ 20Institutes\%20of\%20Health. 